\title{
Evaluation of Curing and Drying Methods on the Physical Quality of Turmeric (Curcuma Longa L.) Rhizome Grown in South Western Ethiopia
}

\author{
Biruk Hirko* \\ Tepi Agricultural Research Center, P. O. Box 34, Tepi, Ethiopia
}

*Corresponding Author: Biruk Hirko, Tepi Agricultural Research Center, P. O. Box 34, Tepi, Ethiopia

\begin{abstract}
A study was conducted to determine the effects of boiling time, rhizome form and drying methods on the physical quality characteristics of turmeric. The experiment consisted of four levels of boiling times; two levels of rhizome forms and two levels of drying methods laid out in a $4 \times 2 \times 2$ factorial arrangement using completely Randomized Design. Highest recovery percentages of 20.45 and $19.20 \%$ were attained from the shortest (15 min) boiling time of unsliced samples dried in sun. Most of the high rated (3.17 to 3.68) powder colour were obtained from unsliced samples regardless of boiling time and drying methods. In Poly tunnel solar drier products retained good colour and recommended moisture content than the open-air sun -dried samples. Boiling for 60 minutes then slicing paired with sun drying resulted in a loss of rhizome colour and powder colour quality. Loss of colour was observed more on sliced rhizome than unsliced ones. Among the techniques studied, unsliced rhizome boiled for 15 minutes followed by poly tunnel solar drying was found superior based on the physical quality analysis and concluded for future study on turmeric processing.
\end{abstract}

Keywords: Boiling time, curing methods, finger rhizome, quality, rhizome form, turmeric

\section{INTRODUCTION}

The determination of physical properties of agricultural materials is important to design machines and processes for harvesting, handling and storage of these materials and finally to be used as food and feed product. For agricultural materials, dimensions (length, diameter, thickness) are widely used to describe them. The physical dimension of turmeric rhizome especially shape is very important in sorting and sizing, and specify the number of rhizomes to behold for material handling of a given size (Keramat et al., 2008). The period at which boiling is stopped largely affects the final colour and aroma of the final product. After boiling the rhizomes are allowed to dry. Traditionally sun drying of turmeric is extremely weather-dependent and requires unduly long processing times (20 to 30 days) and to some extent leads to prone to infestation, which is not acceptable for industry (Bambirra et al., 2002).

The postharvest processing of turmeric involves many units operations such as washing, cleaning, curing or blanching, drying, polishing, size reduction and packaging. The duration when boiling is stopped significantly affect the colour and aroma of the final product. Over-cooking spoils the colour of the final product while under-cooking renders the dried product brittle (Weiss, 2002). Post-harvest processing of turmeric was not much explored to get quality products. In our country, the main contributing factors for low quality products had been the absence of appropriate curing and drying methods to meet the internationally required physical quality standards that is a problem among farmers, investors and exporters and need further study. For these reasons, this study was undertaken with the objectives to assess the effect of curing methods (boiling times and rhizome forms) and drying methods on turmeric physical quality.

\section{Materials AND Methods}

\subsection{Description of the Study Area}

The experiment was conducted at Tepi Agricultural Research Center which is located in southwestern Ethiopia. The area receives mean annual rainfall of $1688 \mathrm{~mm}$ with maximum and minimum temperatures of $29.5 \mathrm{oC}$ and $15.3 \mathrm{oC}$, respectively (Edossa, 1998b). The soil is reddish-brown sandy clay loam categorised as nitosol with a pH range of 5.60 to 6.0 (Girma et al., 2009b). 


\subsection{Experimental Materials}

Turmeric rhizome of Dame Variety was collected from Tepi Agricultural Research Centre (TARC) seed multiplication plot on January 2018. Fully mature turmeric rhizomes were manually dug out from the soil by spade, cleaned from mud and other extraneous matter adhering to them. The finger rhizomes were separated from mother rhizomes and washed by water to remove all soil remnants, tiny roots and later spread on mesh wire to drain the water. About $4.5 \mathrm{~kg}$ of turmeric finger rhizome was used in one running for each experimental unit.

\subsection{Experimental Design and Statistical Analysis}

The experiment consisted of three main factors, namely boiling time, drying method and rhizome form. The boiling time had four levels i.e. 15, 30, 45 and 60 minutes. The drying method consisted of two types (direct sun drying and poly tunnel solar drying). The rhizome forms were two, i.e. sliced and unsliced. This way the experiment consisted of a $4 \times 2 \times 2$ arrangement resulting in a total of 48 with replications laid out in a Completely Randomized Design (CRD) Factorial design. Each treatment was done in triplicates. Analysis of variance was performed using the ANOVA procedure of SAS Statistical Software 9.2 version. The mean comparison was undertaken with LSD at $5 \%$ when significant treatment effects were observed.

Table1. Treatments, descriptions and their respective combinations for the experiment.

\begin{tabular}{|c|c|c|c|c|}
\hline \multirow{3}{*}{ Boiling Time } & \multicolumn{4}{|c|}{ Rhizome form and drying method } \\
\hline & \multicolumn{2}{|c|}{ NS } & \multicolumn{2}{|c|}{ SL } \\
\hline & $\mathrm{SD}$ & PTS & $\mathrm{SD}$ & PTS \\
\hline $15 \mathrm{~min}$ & $15 \operatorname{minNSSD}$ & 15 minNSPTS & $15 \operatorname{minSLSD}$ & 15 minSLPTS \\
\hline $30 \mathrm{~min}$ & $30 \operatorname{minNSSD}$ & $30 \operatorname{minNSPTS}$ & $30 \operatorname{minSLSD}$ & $30 \mathrm{minSLPTS}$ \\
\hline $45 \mathrm{~min}$ & $45 \operatorname{minNSSD}$ & 45 minNSPTS & $45 \mathrm{minSLSD}$ & 45 minSLPTS \\
\hline $60 \mathrm{~min}$ & $60 \operatorname{minNSSD}$ & $60 \operatorname{minNSPTS}$ & $60 \mathrm{minSLSD}$ & 60 minSLPTS \\
\hline
\end{tabular}

Min= Minutes; NS= Non-Sliced, SL=Sliced SD= Sun Drying, PTS= poly Tunnel Solar Drying.

Boiling time: - Curing of rhizomes is attained by boiling at $980 \mathrm{oC}$ using a 15 litre capacity stainless steel water heater. The electrical heater had a maximum of 220 volts, 5000 watts and up to $1100^{\circ} \mathrm{C}$ temperature range. The temperature of the hot water is controlled thermostatically. The ratio of sample mass to water volume was 1:2. About 10 litres of water was filled in a heater and boiled to the desired temperature of $98^{\circ} \mathrm{C}$. Then each finger of $4.5 \mathrm{~kg}$ was put into the boiling water and left for the required time, i.e. 15, 30, 45 and 60 minutes. When the specified time of boiling was reached the samples were drained to remove the excess water and to stop further boiling. The experiment was done in triplicate. The boiled rhizomes after cooling were divided into two groups before drying. One group is directly sent to the dryers to be dried in direct sunlight (sun drying) and/or poly tunnel solar drier. The second group were sliced manually perpendicularly at a thickness of $10 \mathrm{~mm}$. The sliced rhizome was further divided into two to be dried in direct sunlight (sun drying) and the polytunnel solar dryer. The hot water treatment was set based on the method reported by (Shibru et al., 2017) and the slicing treatment was according to (Prasad et al., 2006).

\section{$>$ Drying Method}

Drying was performed in direct sunlight (sun drying) and a poly tunnel solar dryer simultaneously at the same weather condition.

\section{$>$ Sun Drying}

The processed turmeric rhizome was spread into two metallic stands with two trays made up of mesh wire each having $1.40 \mathrm{~m}$ height above the ground and partitioned by $70 \mathrm{~cm} \times 50 \mathrm{~cm}$ tray length and width.

\section{$>$ Polytunnel Solar Dryer Set Up}

Poly tunnel solar dryer (PTSD) with $50 \mathrm{~m} 2$ base area was used. Tunnel shaped semi-cylindrical solar drier had a size of $10 \mathrm{~m} \times 5 \mathrm{~m} \times 2.7 \mathrm{~m}$ of length, width and height, respectively. The roof and drying chamber were constructed with the hoop structure covered with UV-stabilized transparent polyethylene sheet $(0.2 \mathrm{~mm}$ thickness). In the front side of the poly tunnel solar dryer, a door of $1.2 \mathrm{~m}$ x $2 \mathrm{~m}$ covered by UV-stabilized transparent polyethylene sheet was provided to access to the inlet. 
Two windows $0.9 \mathrm{~m} \times 0.6 \mathrm{~m}$ were provided to remove the moist air. Inside the drier, the floor was constructed with cement and two metallic stands with two trays. It was divided into 8 parts with equal dimensions containing mesh trays of $70 \mathrm{~cm} \times 50 \mathrm{~cm}$ tray mesh fitted on the metallic stand.

Temperature and Relative Humidity Measurements

Ambient air and solar drier temperature, as well as relative humidity, were recorded hourly from 08:00 am to 5:00 pm using a digital thermo-hygrometer (model HTC-1).

\subsection{Data Collected}

\subsubsection{Physical Characteristic of Turmeric Finger Rhizome}

\section{$>$ Dry Recovery Percent (DR \%)}

Was calculated by noting the differences between fresh and dry weight. Dry recovery was calculated from fresh weight (W1) taken before boiling (curing) and then dried and polished weight (W2) taken after drying and expressed in percentage.

$\mathrm{DR}(\%)=100-\left[\frac{(\mathrm{W} 1-\mathrm{W} 2)}{\mathrm{W} 1} * 100\right]$

$\mathrm{W} 1=$ fresh weight before boiling;

$\mathrm{W} 2=$ dried and polished weight after drying

$>$ Corkish Layer $(C L)$

Was determined by weighing the final dried sample before polishing and after polishing. The differences in weight were used against the weight of the sample before polishing.

CL $(\%)=\frac{\text { Weight of sample before polishing }- \text { Weight of sample after polishing }}{\text { Weight of sample before polishing }} * 100$

Percentage of Length Shrinkage

From $4.5 \mathrm{~kg}$ of bulk rhizomes, 100 rhizomes were taken randomly for the preliminary test to get the average length of the rhizomes by using vernier calliper with $0.01 \mathrm{~mm}$ accuracy. The relative average length of the turmeric rhizomes $5-8 \mathrm{~cm}$ in length and $1-3 \mathrm{~cm}$ in width were used. From 100 rhizomes which were randomly selected the average length were taken as (L1); dried and polished rhizome as (L2) and converted into a percentage of reduction. The same rhizome selection procedure was used for sliced rhizome and in this case measurement of length and thickness was taken after boiling duration were under taken.

$\% \mathrm{LS}=\frac{\mathrm{L} 1-\mathrm{L} 2}{\mathrm{~L} 1} \mathrm{X} 100$

$\mathrm{L} 1=$ Average length of fresh rhizome; $\mathrm{L} 2=$ Average length of the dried and polished rhizome

\section{$>$ Percentage of Thickness Shrinkage}

The percentage length procedure was used for thickness shrinkage determination by substituting thickness instead of length and converted to percentage.

Thickness Shrinkage $(\% \mathrm{TS})=\frac{\mathrm{T} 1-\mathrm{T} 2}{\mathrm{~T} 1} \mathrm{X} 100$

$\mathrm{T} 1=$ Average length of fresh rhizome; $\mathrm{T} 2=$ Average length of the dried and polished rhizome

\section{$>$ Colour of Dried Whole Rhizomes and Powders}

The colours of powder were determined subjectively by rating method under categories of yellowish orange (rating=4), yellow (rating=3), light yellow (rating=2) and dull yellow (rating=1). Colour of the whole rhizomes was judged into yellow orange (rating=4), yellow (rating=3), yellowish brown (rating=2) and dull brown (rating=1). The rating and categorizing the rhizomes into their nearest colour was judged based on the method of Fantahun and Teklu (1995) as cited in Girma et al. (2008).

\section{$>$ Determination of Turmeric Powder Moisture Content}

The moisture content was estimated according to AOAC (2000) method. Empty dish and lid were dried in the oven at $105^{\circ} \mathrm{C}$ for 3 hours and desiccated to cool. The empty dish and lid was weighed as (W1) and $3 \mathrm{~g}$ powdered sample was placed in the dish and weighted as (W2). The sample was dried at $105^{\circ} \mathrm{C}$ for 3 hours and weighed as (W3). Percentage of moisture content was calculated on a wet basis (w.b). 
Moisture content $(\% \mathrm{w} . \mathrm{b})=\frac{\mathrm{W} 3-\mathrm{W} 1}{\mathrm{~W} 2-\mathrm{W} 1} * 100$

$\mathrm{W} 1=$ Weight of empty dish and lid; W2= Weight of empty dish and lid with sample

W3=Weight of empty dish and lid with dried sample

\section{RESUlTS AND DISCUSSIONS}

\subsection{Temperature and Relative Humidity Variation during Drying}

Figure1 shows the records of operating conditions during the drying period of turmeric finger rhizome samples. Temperature and RH data in the solar dryer and ambient air showed either a definite decrease or increase in the daily record. The average ambient temperature reads $23.19^{\circ} \mathrm{C}$ at 8:00 am and kept increasing until it reaches the peak $30.66^{\circ} \mathrm{C}$ at $1: 00 \mathrm{pm}$. In the afternoon it drops slowly reaching $27.39^{\circ} \mathrm{C}$ at 5:00 $\mathrm{pm}$. The temperature data of tunnel solar dryer shows values beginning from 25.72 at 8:00 am to the maximum $47.02^{\circ} \mathrm{C}$ at $1: 00 \mathrm{p} . \mathrm{m}$. It can be seen from the data the differential temperature between the tunnel solar dryer and the ambient ranged from $2^{\circ} \mathrm{C}$ in the mornings up to $16^{\circ} \mathrm{C}$ at 1:00 p.m. On the average there exists differential temperature of more than $10^{\circ} \mathrm{C}$ between the two methods of drying.

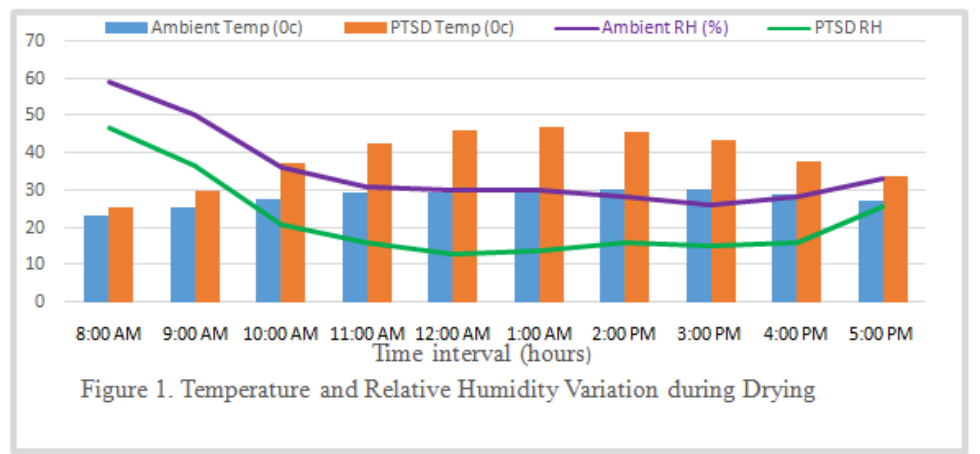

\subsection{Main Effects of Processing Methods on Physical Quality of Turmeric Rhizome.}

\subsubsection{Recovery Percent (RP \%)}

Data of physical quality attributes of turmeric rhizomes as affected by processing methods are presented in Table 2. The effect of boiling time showed that significant $(\mathrm{P}<0.05)$ differences existed in the dry recovery of the rhizomes with values of 19.02, 18.65, 18.40 and $18.24 \%$ for boiling times of $15,30,45$ and 60 minutes, respectively. This implies as boiling time increased the recovery rate decreased. This could be attributed to the loss of soluble solids in the boiling water which increased with length of the boiling time. The dry recovery of cured turmeric varied between 15-30\% (Peter, 2007). The recovery is also influenced significantly $(\mathrm{P}<0.05)$ by rhizome form. The percent recovery of the unsliced samples was $18.90 \%$ and is different from $18.28 \%$ of the sliced samples. Slicing the rhizomes prior to drying reduces drying time and yields turmeric with lower moisture content and better curcuminoid extractability (Govindarajan, 1980; Buescher and Yang, 2000).

The drying method also exhibited a significant difference in the dry recovery with values of 18.28 and $18.90 \%$ for Poly tunnel solar drier and sun drying, respectively. This may be due to the lower average temperature $\left(28.27^{\circ} \mathrm{C}\right)$ received in ambient air sun drying which may have resulted in lower evaporation rate than the average temperature $39.03^{\circ} \mathrm{C}$ in poly tunnel solar dryer (PTSD). However, Khan et al. (2016) reported total recovery (yield, \%) of rhizomes dried by mechanical drier was slightly more (26.4\%) than that of sun dried samples (25.1\%).

Table2. Effect of boiling duration, drying method and rhizome form on physical quality of turmeric rhizome.

\begin{tabular}{|c|c|c|c|c|}
\hline Treatments & $\begin{array}{c}\text { Recovery } \\
\text { percent }(\boldsymbol{\%})\end{array}$ & $\begin{array}{c}\text { Thickness } \\
\text { shrinkage (\%) }\end{array}$ & $\begin{array}{c}\text { Length } \\
\text { shrinkage (\%) }\end{array}$ & $\begin{array}{c}\text { Powder color } \\
\text { (rating) }\end{array}$ \\
\hline Boiling time & & & & $3.34^{\mathrm{a}}$ \\
\hline $15 \mathrm{~min}$ & $19.02^{\mathrm{a}}$ & $51.76^{\mathrm{b}}$ & $31.63^{\mathrm{b}}$ & $3.21^{\mathrm{b}}$ \\
\hline $30 \mathrm{~min}$ & $18.65^{\mathrm{b}}$ & $52.48^{\mathrm{a}}$ & $32.47^{\mathrm{ab}}$ & $3.06^{\mathrm{c}}$ \\
\hline $45 \mathrm{~min}$ & $18.43^{\mathrm{bc}}$ & $52.95^{\mathrm{a}}$ & $32.07^{\mathrm{b}}$ & $2.92^{\mathrm{d}}$ \\
\hline $60 \mathrm{~min}$ & $18.24^{\mathrm{c}}$ & $53.06^{\mathrm{a}}$ & $34.70^{\mathrm{a}}$ & ${ }^{\mathrm{a}}$ \\
\hline
\end{tabular}


Evaluation of Curing and Drying Methods on the Physical Quality of Turmeric (Curcuma Longa L.) Rhizome Grown in South Western Ethiopia

\begin{tabular}{|c|c|c|c|c|}
\hline LSD $(5 \%)$ & 0.28 & 0.58 & 2.33 & 0.10 \\
\hline \multicolumn{5}{|l|}{ Rhizome form } \\
\hline NS & $18.90^{\mathrm{a}}$ & $51.94^{b}$ & $31.83^{b}$ & $3.26^{\mathrm{a}}$ \\
\hline SL & $18.26^{\mathrm{b}}$ & $53.20^{\mathrm{a}}$ & $33.60^{\mathrm{a}}$ & $3.01^{\mathrm{b}}$ \\
\hline LSD (5\%) & 0.19 & 0.41 & 1.64 & 0.07 \\
\hline \multicolumn{5}{|l|}{ Drying method } \\
\hline SD & $18.90^{\mathrm{a}}$ & $52.46^{\mathrm{a}}$ & $31.75^{\mathrm{b}}$ & $3.26^{\mathrm{a}}$ \\
\hline PTSD & $18.28^{\mathrm{b}}$ & $52.66^{\mathrm{a}}$ & $33.69^{\mathrm{a}}$ & $3.00^{\mathrm{b}}$ \\
\hline LSD (5\%) & 0.20 & 0.41 & 1.64 & 0.07 \\
\hline CV (\%) & 1.83 & 1.33 & 8.37 & 3.79 \\
\hline
\end{tabular}

Mean values down the columns with the same letters are not significantly different at 5\% level significance. Min= minutes; NS=Unsliced; SL=Sliced; SD=Sun drying; PTSD= Poly tunnel solar drying; CV=Coefficient of variance; $L S D=$ Least significance difference

\subsubsection{Thickness Shrinkage (\%TS)}

The thickness shrinkage level showed significant change for the longer boiling time of 30, 45 and 60 minutes with values of 52.48, 52.95 and $53.06 \%$, respectively, with no difference among themselves, but, statistically higher than the $51.76 \%$ of the samples boiled for 15 minutes only. Similarly, Shibru et al. (2017) reported an increment trend value of 38.30, 40.75, 41.36 and $42.42 \%$ diameter shrinkage as boiling time increased from 30, 45, 60 and 75 minutes, respectively. Similarly, rhizome form caused significant differences $(\mathrm{P}<0.05)$ where unsliced boiled sample resulted in less contractile stress and maintaining the cell structure that resulted in less thickness shrinkage percentage. However this quality parameter was not significantly affected by drying methods. The result indicated that thickness shrinkage direction recorded more shrinkage than length shrinkage and this may be due to more water molecules moved in the radial direction of turmeric finger rhizome during drying, more void space is formed between solid particles that caused contraction of the cell wall in case of turmeric. This was supported by Parveen et al. (2013) that turmeric finger rhizomes recorded $50.54 \%$ reduction in thickness.

\subsubsection{Length Shrinkage (\%LS)}

Data presented in Table 2 indicated length shrinkage values as the boiling time 15, 30 and 45 minutes did not have a significant effect, unlike the 60 minutes boiling which resulted in significantly higher (34.70\%) shrinkage. The sliced rhizome recorded $33.6 \%$ length shrinkage, which is statistically $(\mathrm{P}<0.05)$ higher than the $31.8 \%$ of the unsliced samples. Similarly, the drying method caused significant differences $(\mathrm{P}<0.05)$ with $33.69 \%$ shrinkage for the tunnel dried samples as compared with the $31.75 \%$ of the sun dried ones. The higher temperature in the tunnel during drying might have led to more shrinkage of the rhizomes tissues. Similarly, Parveen et al. (2013) reported turmeric finger rhizomes recorded $27.38 \%$ reduction in length when the moisture content was reduced from 411.25 to $7.81 \%$ (d.b). Mayor and Sereno, (2004) reported that on agricultural products water loss and heating cause stresses in their cellular structure causing a significant change in shape and decrease in dimension.

\subsubsection{Powder Colour (rating)}

The powder colour rating was influenced by boiling time with significant $(\mathrm{P}<0.05)$ differences and presented in Table 2. The loss of more colour pigments observed as the boiling time extended. In this study, about $12 \%, 8.38 \%$ and $3.9 \%$ loss of powder colour were observed from 60,45 , and 30 minutes boiled samples. Similarly, Joshi et al. (2009) reported a 3\%, 5\% and 12\% decrease because of heating for 10,30 or $60 \mathrm{~min}$. In case of rhizomes form, the unsliced samples were rated 3.26, significantly higher than the 3.01 rating of the sliced samples. The sliced samples could lose more colour pigment than the unsliced ones as the protective skin is gone exposing the internal tissue to the external environment.

Regarding the drying method tunnel dried samples were rated 3.26 between (yellowish to yellowish orange) and statistically higher than the 3.00 (yellowish rating) of the sun dried samples. The less intensity of colour in sun dried samples may be due to the direct effect of sun light which faded or degraded the colour of turmeric. Anandaraj et al. (1989) also found that direct sunlight results in surface discolouration of turmeric rhizomes with poor quality powder. Joshi et al. (2009) also stated the inferior in all the quality attributes viz. colour, flavour, appearance and overall acceptability for sun dried samples. 


\subsection{Effect of Interactions Among Boiling Time, Rhizome form and Drying Methods on Physical Quality Attributes of Turmeric}

\subsubsection{Corkish Layer (\%CL)}

Percent of corkish layer was significantly $(\mathrm{P}<0.05)$ influenced by all interactions giving the highest $10.53 \%$ for sliced samples, boiled for 60 minutes and dried in the tunnel. On the other side, the lowest percentage of corkish layer $4.60 \%$ is recorded for unsliced sample boiled for the shortest time (15 min) and dried in the open sun. The highest boiling time leads to the more destruction of outer cells of rhizomes which have a significant role for removal of outer peel during drying period and polishing.

Table3. Interaction effect among boiling time, drying method and rhizome form on physical quality of turmeric.

\begin{tabular}{|c|c|c|c|c|c|}
\hline $\begin{array}{l}\text { Boiling } \\
\text { time }\end{array}$ & $\begin{array}{l}\text { Drying } \\
\text { method }\end{array}$ & $\begin{array}{c}\text { Rhizome } \\
\text { form }\end{array}$ & $\begin{array}{c}\text { Corkish } \\
\text { Layer }(\%) \\
\end{array}$ & $\begin{array}{c}\text { Rhizome color } \\
\text { (rating) }\end{array}$ & $\begin{array}{c}\text { Moisture Content } \\
(\%)\end{array}$ \\
\hline \multirow{4}{*}{$15 \min$} & \multirow{2}{*}{ SD } & NS & $4.60^{j}$ & $1.88^{\mathrm{f}}$ & $11.05^{\mathrm{a}}$ \\
\hline & & SL & $6.43^{\text {hi }}$ & $2.75^{b}$ & $10.11^{\mathrm{bcd}}$ \\
\hline & \multirow{2}{*}{ PTSD } & NS & $5.86^{\mathrm{i}}$ & $2.13^{\text {cde }}$ & $10.22^{\text {bcd }}$ \\
\hline & & SL & $7.13^{\text {gh }}$ & $2.73^{\mathrm{b}}$ & $9.96^{\mathrm{cd}}$ \\
\hline \multirow{4}{*}{$30 \mathrm{~min}$} & \multirow{2}{*}{ SD } & NS & $7.53^{\mathrm{efg}}$ & $2.05^{\mathrm{e}}$ & $10.67^{\mathrm{ab}}$ \\
\hline & & $\mathrm{SL}$ & $6.80^{\mathrm{ghi}}$ & $2.73^{\mathrm{b}}$ & $10.38^{\mathrm{bc}}$ \\
\hline & \multirow{2}{*}{ PTSD } & NS & $7.63^{\text {defg }}$ & $2.13^{\text {cde }}$ & $9.95^{\mathrm{cd}}$ \\
\hline & & SL & $9.70^{\mathrm{ab}}$ & $2.92^{\mathrm{a}}$ & $9.70^{\mathrm{de}}$ \\
\hline \multirow{4}{*}{$45 \min$} & \multirow{2}{*}{ SD } & NS & $7.36^{\text {efgh }}$ & $2.10^{\mathrm{de}}$ & $10.07^{\text {cd }}$ \\
\hline & & SL & $7.46^{\text {efg }}$ & $2.71^{\text {be }}$ & $10.10^{\text {bcd }}$ \\
\hline & \multirow{2}{*}{ PTSD } & NS & $8.33^{\mathrm{de}}$ & $2.16^{\text {cde }}$ & $9.90^{\text {cde }}$ \\
\hline & & SL & $9.53^{\mathrm{bc}}$ & $2.83^{\mathrm{ab}}$ & $9.98^{\mathrm{cd}}$ \\
\hline \multirow{4}{*}{$60 \mathrm{~min}$} & \multirow{2}{*}{ SD } & $\mathrm{NS}$ & $7.26^{\mathrm{fgh}}$ & $2.22^{\mathrm{cd}}$ & $10.47^{\mathrm{bc}}$ \\
\hline & & SL & $8.20^{\mathrm{def}}$ & $2.77^{b}$ & $10.17^{\text {bcd }}$ \\
\hline & \multirow{2}{*}{ PTSD } & NS & $8.56^{\mathrm{cd}}$ & $2.25^{\mathrm{c}}$ & $9.64^{\mathrm{de}}$ \\
\hline & & SL & $10.53^{\mathrm{a}}$ & $2.73^{b}$ & $9.36^{\mathrm{e}}$ \\
\hline \multicolumn{3}{|c|}{ LSD (5\%) } & 0.98 & 0.15 & 0.57 \\
\hline \multicolumn{3}{|c|}{$\mathrm{CV}(\%)$} & 7.71 & 3.58 & 3.42 \\
\hline
\end{tabular}

Mean values down the columns with the same letters are not significantly different at $5 \%$ level significance. Min=minutes; NS=Unsliced; SL=Sliced; SD=Sun drying; PTSD= Poly tunnel solar drying; CV=Coefficient of variance; $\mathrm{LSD}=$ Least significance difference

This condition is more observed due to the easy removal of peel and moisture as the effect of higher mean temperature of $39.03^{\circ} \mathrm{C}$ recorded in Poly tunnel solar dryer than the $28.27^{\circ} \mathrm{C}$ temperature received in ambient air sun drying and sliced form of the rhizome.

\subsubsection{Rhizome Colour (Rating)}

Interaction effects among boiling duration, rhizome form and drying methods had shown significant differences $(\mathrm{P}<0.05)$ on rhizome colour. The rhizome colour rating value ranged from 2.92 of sliced samples, boiled for 30 minutes and dried in tunnel to the lowest value of 1.88 of unsliced samples, boiled for 15 minutes and dried in the open sun. Shibru et al. (2017) reported rhizomes which were boiled at the highest temperature level with duration of boiling increasing from the 30 minutes to 75 minutes, there lead to the formation of the wrinkled form of products.

Extended boiling time contact of heat on rhizomes during boiling led to ease of rubbing and increase colour intensity after polishing. Increment of rhizome colour intensity was highly observed when combined with poly tunnel solar drying and sliced form of rhizome. This may be due to the high temperature observed in PTSD and sliced rhizome form leads to ease of polishing the outer layer of rhizome. Similarly, Weiss, (2002) concluded the stage at which boiling is stopped largely influences the colour and aroma of the final product. Prolonged boiling duration leads to discolouration of the final product while under-cooking renders the dried product brittle.

\subsubsection{Moisture Content (\%)}

Data of physical quality attributes of turmeric rhizomes as influenced by the interacting boiling time, rhizome form and drying methods are shown in Table 3. The moisture content of the sample varied 
significantly $(\mathrm{p}<0.05)$ among interactions. The moisture content of fresh turmeric rhizome was $77.7 \%$ and dried to the range between $9.36 \%$ of the highest boiling time $(60 \mathrm{~min})$ of sliced rhizome dried in polytunnel solar drying to $11.05 \%$ of unsliced rhizome boiled for $30 \mathrm{~min}$ and sun dried sample. The interaction effect is dominated by the rhizome form and drying method.

\section{CONCLuSion}

An experiment was conducted to evaluate the effect of curing methods viz. (boiling time and rhizome form) and drying methods viz (Polytunnel solar drying and direct sun drying) on turmeric physical quality. Interaction effects among boiling duration, rhizome form and drying methods had shown significant differences $(\mathrm{P}<0.05)$ on some of the physical parameters (rhizome color, corkish layer and moisture content). As the boiling time extended the recovery percent, powder colour acceptability, thickness shrinkage and length shrinkage decreased. In this study, about $12 \%, 8.38 \%$ and $3.9 \%$ loss of powder color was observed from 60, 45, and 30 minutes boiled samples, respectively. Sun drying had a significant loss on quality and resulted in lower physical rhizome quality attributes than polytunnel solar drier. This was more prominent from unsliced rhizome than from sliced one. From this study, it can be concluded that shorter boiling time of 15 minutes, unsliced rhizome form and use of the polytunnel solar dryer give the product of highly acceptable quality characteristics.

\section{ACKNOWLEDGMENT}

The authors would like to acknowledge all Tepi Agricultural Research spices research team and the Ethiopian Institute of Agricultural Research for funding.

\section{REFERENCES}

[1] Keramat, J. M., Rafiee, S., Jafari, A., Ghasemi, B.M.R., Mirasheh, R. and Mohtasebi, S.S. 2008. Some physical properties of date Rhizome (cv. Dairi). International Agro Physics, 22(1): 221-224.

[2] Bambirra, M.L.A., Junqueira, R.G., and Glória, M.B.A. 2002. Influence of postharvest processing conditions on yield and quality of ground turmeric (Curcuma longa L.). Brazilian Archives of Biology and Technology, 45(4): 423-429.

[3] Weiss, E.A. 2002. Spice Crops. CAB International publishing, Oxon, UK.

[4] Edossa, E. 1998b. Spices research achievements and experiences. Research Report No. 33. Institute of Agricultural Research, Addis Ababa Ethiopia, 5-45.

[5] Girma,H., Digafie, T and Tekaligne, T. 2009b. Physical parameters, oleoresin and volatile oils content of five pepper (Piper nigrum L.) cultivars as influenced by maturity. East African Journal of Sciences, 3(2):189-192.

[6] Shibru, Z.F., Ali, M., Girma, H and John, B. 2017. Influence of boiling temperature levels and durations on the physical quality of different rhizomes set types of turmeric (Curcuma longa $\mathrm{L}$.). International Journal of Current Research in Life Sciences, 06(03):668-678.

[7] Prasad, J., Vijay, V.K., Tiwari, G.N. and Sorayan, V.P.S. 2006. Study on performance evaluation of hybrid drier for turmeric (Curcuma longa L.) drying at village scale. Journal of Food Engineering, 75(4): $497-$ 502 .

[8] Fantahun, L and Teklu, N. 1995. Spices crops processing: Constraints and Possibilities; In Workshop on Coffee and Associated Crops, Feb. 27 - March 1/1995. Addis Ababa, Ethiopia, pp.1-10.

[9] Girma, H and Kindie, T. 2008. The effects of seed rhizome size on the growth, yield and economic return of ginger (Zingiber officinale Rose.). Asian Network for Scientific Information. Asian Journal of Plant Sciences, 7(2):213-217.

[10] AOAC (Association of Official Analytical Chemists). 2000. Official Methods of Analysis. $17^{\text {th }}$ edition, Washington D.C.

[11] Peter, V.K. 2007. Handbook of herbs and spices. Published in North America by CRC Press LLC, 2000 Corporate Blvd, NW Boca Raton FL 33431, USA. Wood head Publishing Ltd.

[12] Govindarajan, V.S. 1980. Turmeric - chemistry, technology, and quality. Critical Review in Food Science and Nutrition. T.E. Furia, Ed., CRC Press, Boca Raton, FL. 12:199-301.

[13] Buescher, R.W. and Yang, L. 2000. Turmeric: In Lauro, G. J. and Francis, F. J. (Eds). Natural Food Colorants, New York: Marcel Dekker Inc. Pp205-226.

[14] Khan, A.S., Ahmad, N., Ahmad, H. and Mahmood, M.A. 2016. Mechanical Drying Influences Postharvest Quality of Turmeric Rhizomes. In Proceedings of Pakistan Society for Horticultural Science 2nd International Conference on Horticultural Sciences, p345-353. 
Evaluation of Curing and Drying Methods on the Physical Quality of Turmeric (Curcuma Longa L.) Rhizome Grown in South Western Ethiopia

[15] Parveen, S., Kailappan, R. and Dhananchezhiyan, P. 2013. Studies on shrinkage of turmeric rhizomes during drying. International Journal of FoodNutrition and Science, 2(2):30-40.

[16] Mayor, L. and Sereno, A.M. 2004. Modelling Shrinkage during Convective Drying of Food Materials: a Review. Journal of Food Engineering, 61(3): 373- 386

[17] Joshi, P., Jain, S. and Sharma, V., 2009. Turmeric (Curcuma longa) a natural source of edible yellow colour. International journal of food science and technology, 44(12):2402-2406.

[18] Anandaraj, M., Devasahayam, S., Zachariah, T.J., Eapen, S.J., Sasikumar, B. and Thankamani, C.K. 1989. Turmeric (Extension Pamphlet). Indian Institute of Spices Research, Calicut, Kerala. API-Ayurvedic Pharmacopoeia of India, pp.45-46.

Citation: Biruk Hirko, "Evaluation of Curing and Drying Methods on the Physical Quality of Turmeric (Curcuma Longa L.) Rhizome Grown in South Western Ethiopia” International Journal of Research Studies in Agricultural Sciences (IJRSAS), 2019; 5(11), pp. 18-25, http://dx.doi.org/10.20431/2454-6224.0511003

Copyright: (C) 2019 Authors. This is an open-access article distributed under the terms of the Creative Commons Attribution License, which permits unrestricted use, distribution, and reproduction in any medium, provided the original author and source are credited. 